\title{
DEPLOYMENT OF ERTMS IN CZECH REPUBLIC
}

\author{
JiŘí VopaVA*, MÁRIA JÁneŠOVÁ, RADEK KRATOChVÍl \\ CTU in Prague, Czech Technical University in Prague - Faculty of Transportation Sciences, Konviktská 20, \\ 110 00, Prague \\ * corresponding author: jiri.vopava@gmail.com
}

\begin{abstract}
The article describes current situation and expected deployment of international standard for automatic rail vehicle protection in Czech Republic for period $2014-2020$. Article introduces expected status in 2020 and subsequent implementation of commitments until 2026. It introduces expected result of gradual implementation for tracks and vehicles. It also displays brief deployment overview of European Rail Traffic Management System in European Union countries for each level of European Train Control System.
\end{abstract}

KEYWORDS: ERTMS, ETCS, GSM-R, Interoperability.

\section{INTRODUCTION}

The ERTMS is automatic train protection which represents basic part of interoperability in European rail system. The term is abbreviation of "European Rail Traffic Management System" and it was defined to synchronize nationals systems to the one common compatible system. Urgency of the unification and cooperation between European countries caused an increase in freight which had negative impact for environment and ecology. The implementation of interoperability and automatic train protection across European countries allows competition to air and car freight. Implementation of the standard is business initiative that transforms the operation of the tracks, enhance safety, capacity, performance and reliability. It also have impact on reduce of cost of operation and maintenance.

ERTMS is divided into two basic components. The first one is ETCS "European Train Control System" and second GSM-R "Global System for Mobile Communication for Railway".

The ERTMS allow one compatible system for crossborder traffic what reduce cost for implementation several regional stand-alone systems. The synchronization of automatic train protection increase competitiveness of the European rail sector.

GSM-R "Global System for Mobile Communications - Railway" is a radio system based on GSM standard for providing of voice and data communication between vehicle and track.

ETCS "European Train Control System", is an automatic train protection system to replace the existing national systems. The ETCS replaces about twenty different automatic train protections across European track.

It can be configured to operate in one of the following application levels to enable ETCS equipped vehicles to operate in not ETCS equipped system where the safe movement of the vehicle is controlled by the default national control system:

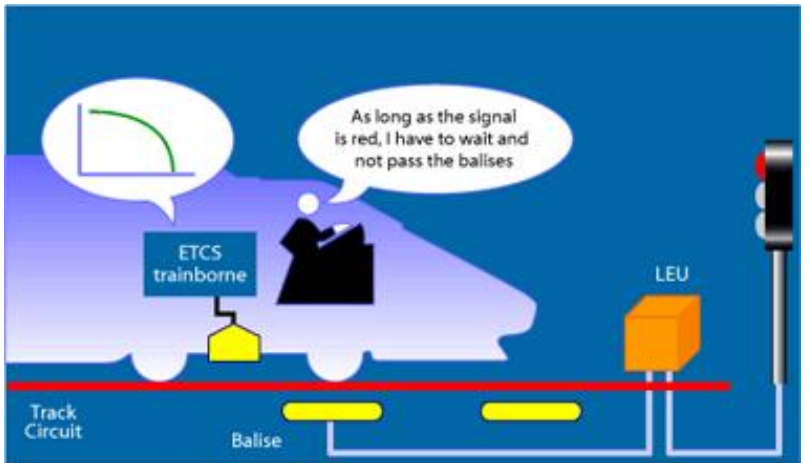

Figure 1. ETCS L1 1]

- Level 0 - ETCS equipped vehicles operating on lines without ETCS system,

- Level 1 - an conventional line-side signal is passed to the train via a switched transmitter on the track, repeating the indication from the conventional signalling system, which continues to be used to support safe train separation. It is the Figure 1 .

- Level 2 - movement authority is passed by the GSM-R radio network from a Radio Block Centre to the train. Conventional train detection systems are utilized in conjunction with interlocking systems used to enforce safe train separation. It is the Figure 2

- Level 3 - it builds on Level 2, but increases safe train separation using critical data from the train. It is the Figure 3

\section{Deployment of ERTMS in Czech Republid}

The Czech Republic contributing to the fulfillment of legal solutions arising from following documents:

- DIRECTIVE 2008/57/EC OF THE EUROPEAN PARLIAMENT AND OF THE COUNCIL 


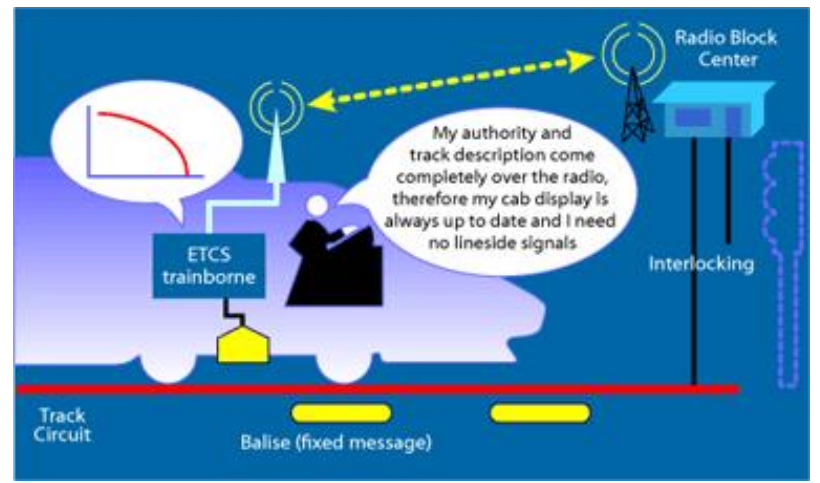

Figure 2. ETCS L2 [1]

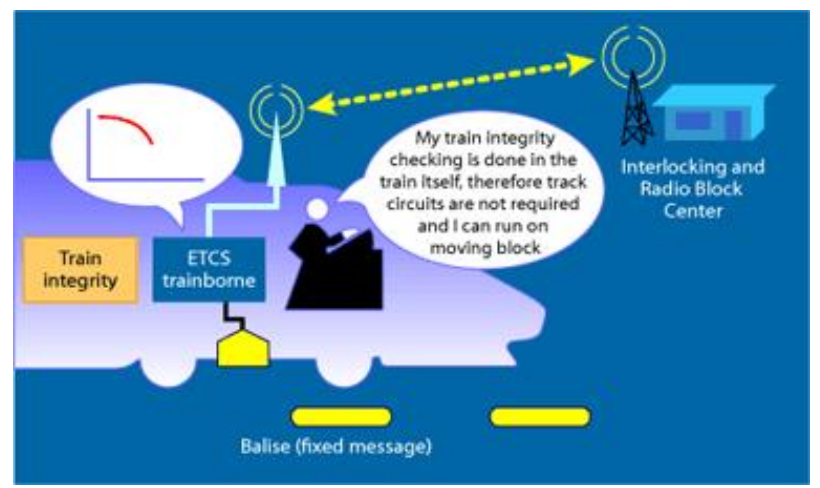

Figure 3. ETCS L3 [1]

of 17 June 2008 on the interoperability of the rail system within the Community

- DECISIONS 2012/88/EU, Commission Decision of 25 January 2012 on the technical specification for interoperability relating to the control-command and signalling subsystems of the trans-European rail system (2012/696/EU a 2015/14/EU)

- REGULATION (EU) No 1315/2013 OF THE EUROPEAN PARLIAMENT AND OF THE COUNCIL of 11 December 2013, on Union guidelines for the development of the transEuropean transport network and repealing Decision No 661/2010/EU

- REGULATION (EU) No 1316/2013 OF THE EUROPEAN PARLIAMENT AND OF THE COUNCIL of 11 December 2013, establishing the Connecting Europe Facility, amending Regulation (EU) No 913/2010 and repealing Regulations (EC) No 680/2007 and (EC) No 67/2010

The deployment is defined in document "Národní implementační plán ERTMS" released by ministry of transport. The document defines maximum amount of payloads for each project GSM-R and ETCS L2 with respect to co-financing from ERTMS funds. It also defines expected deployment schedule of each project.

Between 2005 and 2014 was equipped $1132 \mathrm{~km}$ of tracks across of the Czech Republic. It is connected to

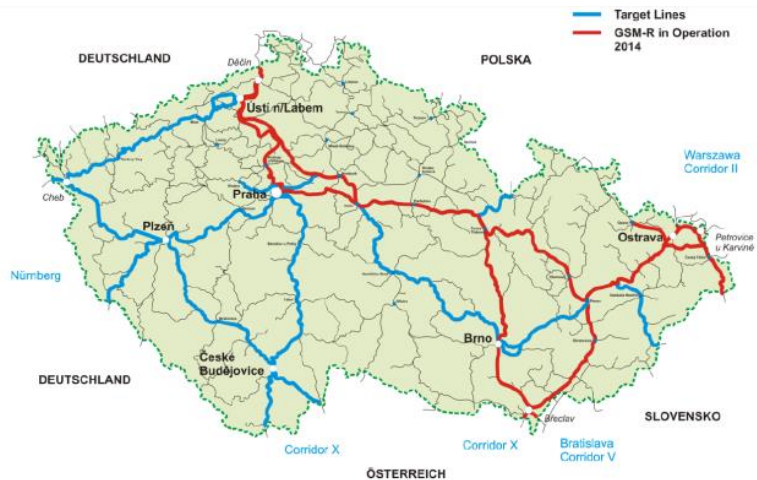

Figure 4. Map of GSM-R implementation 2]

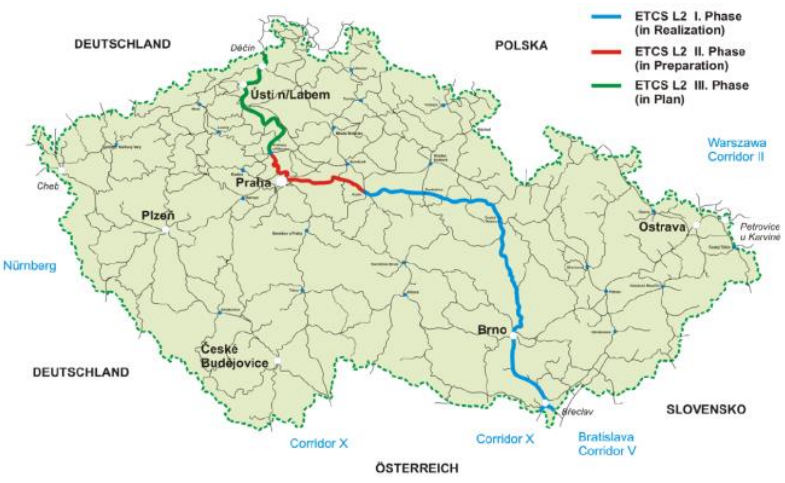

Figure 5. Map of ETCS implementation [2]

the GSM-R SŽDC, DB, ÖBB, ProRail and the home network operator.

There are now mobile terminals equipped with GSM-R all ČD vehicles used in regular operation.

Almost all ČD vehicles used in regular operation are now equipped with GSM-R terminals.

The first stage with fully deployed ETCS system at 2021 will be track "Praha - Česká Třebová - Brno Břeclav".

Following Tables 1, 2, 3 display figures for expected schedule of deployment of GSM-R, ETCS L2 and vehicle on-board equipment for period $2014-2020$ (2026).

The Figure 6 below visualizes data from tables above. It displays total amount of deployments for each year until 2020.

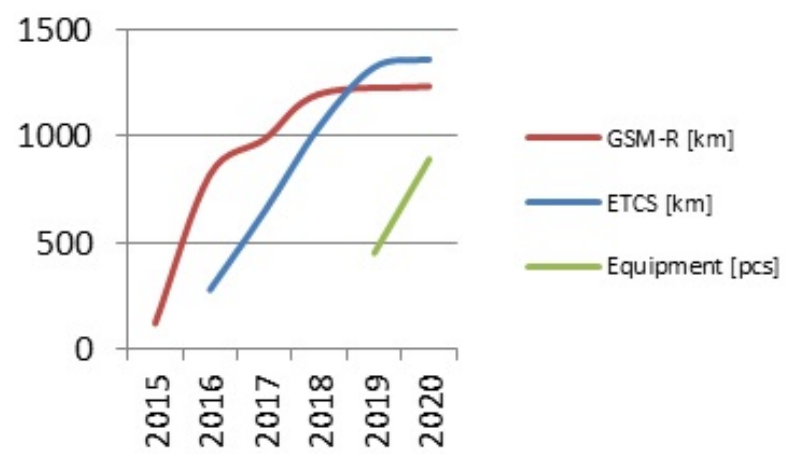

Figure 6. Total amount of expected deployments 


\begin{tabular}{|c|c|c|c|}
\hline No. & Track & Distance $[\mathrm{km}]$ & Deployment \\
\hline 1 & Uzel Praha (Beroun - Praha - Benešov u Prahy - Lysá nad Labem) & 120 & $2014-2015$ \\
\hline 2 & $\begin{array}{l}\text { České Velenice st. hr. Rakousko - České Budějovice - Horní } \\
\text { Dvořiště st. hr. Rakousko }\end{array}$ & 110 & $2015-2016$ \\
\hline 3 & Plzeň - České Budějovice & 136 & $2015-2016$ \\
\hline 4 & Kolín - Havlíčkøuv Brod - Křižanov - Brno & 195 & $2014-2016$ \\
\hline 5 & Benešov - Votice & 20 & $2015-2016$ \\
\hline 6 & Beroun - Plzeň - Cheb st. hr. Německo & 169 & $2014-2016$ \\
\hline 7 & Cheb - Vojtanov st. hr. Německo & 20 & $2015-2016$ \\
\hline 8 & Znojmo - Satov st. hr. Rakousko & 13 & $2015-2016$ \\
\hline 9 & Ústí nad Orlicí - Lichkov st. hr. Polsko & 35 & $2015-2016$ \\
\hline 10 & Votice - České Budějovice & 100 & 2016-2017 \\
\hline 11 & Hranice na Moravě - Horní Lideč st. hr. Slovensko & 67 & 2016-2017 \\
\hline 12 & $\begin{array}{l}\text { Ústí nad Labem - Oldřichov u Duchcova/Úpořiny - Most - Karlovy } \\
\text { Vary - Cheb }\end{array}$ & 212 & 2017-2018 \\
\hline 13 & Pardubice - Hradec Králové & 22 & 2019-2020 \\
\hline 14 & Zábřeh na Moravě - Sumperk & 13 & 2019-2020 \\
\hline 15 & Praha - Letiště V. Havla Ruzyně - Kladno & 31 & after 2020 \\
\hline 16 & Brno - Přerov & 90 & after 2020 \\
\hline 17 & Plzeň - Domažlice st. hr. Německo & 72 & after 2020 \\
\hline \multirow[t]{2}{*}{18} & Velký Osek - Hradec Králové - Choceň & 96 & after 2020 \\
\hline & TOTAL & 1521 & \\
\hline
\end{tabular}

TABLE 1. Expected track deployment with GMS-R [3]

\begin{tabular}{|c|c|c|c|}
\hline No. & Track & Distance $[\mathrm{km}]$ & Deployment \\
\hline 1 & Kolín - Břeclav st. hr. Rakousko/Slovensko & 277 & $2012-2016$ \\
\hline 2 & Kralupy nad Vltavou - Praha - Kolín & 110 & 2016-2017 \\
\hline 3 & st. hr. Německo - Dolní Žleb - Kralupy & 112 & $2017-2019$ \\
\hline 4 & Petrovice u Karviné st. hr. Polsko - Přerov - Břeclav & 206 & $2015-2017$ \\
\hline 5 & Praha-Uhřiněves - Votice & 54 & 2016-2017 \\
\hline 6 & Votice - České Budějovice & 101 & $2017-2018$ \\
\hline 7 & Česká Třebová - Přerov & 110 & $2016-2018$ \\
\hline 8 & Plzeň - Cheb st. hr. Německo & 117 & $2016-2018$ \\
\hline 9 & Beroun - Plzeň & 70 & 2016-2018 \\
\hline 10 & Dětmarovice - Mosty u Jablunkova st. hr. Slovensko & 53 & $2017-2019$ \\
\hline 11 & $\begin{array}{l}\text { České Velenice st. hr. Rakousko - České Budějovice - Horní } \\
\text { Dvořiště st. hr. Rakousko }\end{array}$ & 112 & $2017-2019$ \\
\hline 12 & Ústí nad Orlicí - Lichkov st. hr. Polsko & 37 & $2018-2020$ \\
\hline 13 & Kolín - Nymburk - Mělník - Děčín východ - Děčín-Prostřední Žleb & 159 & after 2020 \\
\hline 14 & Kolín - Havlíčkøuv Brod - Brno & 200 & after 2020 \\
\hline 15 & Praha - Lysá nad Labem & 35 & after 2020 \\
\hline 16 & Praha - Letiště V. Havla Ruzyně - Kladno & 31 & after 2020 \\
\hline 17 & Praha - Beroun & 43 & after 2020 \\
\hline 18 & Plzeň - Domažlice st. hr. Německo & 72 & after 2020 \\
\hline 19 & Pardubice - Hradec Králové & 22 & after 2020 \\
\hline 20 & Plzeň - České Budějovice & 136 & aftre 2020 \\
\hline 21 & Brno - Přerov & 90 & after 2020 \\
\hline 22 & Hranice na Moravě - Horní Lideč st. hr. Slovensko & 67 & after 2020 \\
\hline 23 & Uzel Praha & 40 & after 2020 \\
\hline 24 & Český Těšín - Ostrava-Svinov & 41 & after 2020 \\
\hline 25 & Velký Osek - Hradeck Králové - Choceň & 96 & after 2020 \\
\hline 26 & Cheb - Karlovy Vary - Chomutov & 111 & after 2020 \\
\hline \multirow[t]{2}{*}{27} & Ústí nad Labem - Chomutov, Ústí nad Labem - Bílina & 101 & after 2020 \\
\hline & TOTAL & 2603 & \\
\hline
\end{tabular}

TABLE 2. Expected deployment of equipment upgrade ERTM/ETCS [3] 


\begin{tabular}{|c|c|c|c|}
\hline No. & Track & Distance $[\mathrm{km}]$ & Deployment \\
\hline 1 & Kolín - Břeclav st. hr. Rakousko/Slovensko & 250 & $2015-2019$ \\
\hline 2 & Kralupy nad Vltavou - Praha - Kolín & 100 & $2016-2019$ \\
\hline 3 & st. hr. Německo - Dolní Žleb - Kralupy & 100 & $2017-2019$ \\
\hline 4 & Petrovice u Karviné st. hr. Polsko - Přerov - Břeclav & 130 & $2015-2020$ \\
\hline 5 & Praha-Uhřiněves - Votice & 40 & $2016-2020$ \\
\hline 6 & Votice - České Budějovice & 50 & $2017-2020$ \\
\hline 7 & Česká Třebová - Přerov & 50 & $2016-2020$ \\
\hline 8 & Plzeň - Cheb st. hr. Německo & 40 & $2016-2020$ \\
\hline 9 & Beroun - Plzeň & 40 & $2016-2020$ \\
\hline 10 & Dětmarovice - Mosty u Jablunkova st. hr. Slovensko & 20 & $2017-2020$ \\
\hline 11 & $\begin{array}{l}\text { Ceské Velenice st. hr. Rakousko - Ceské Budějovice - Horní } \\
\text { Dvořiště st. hr. Rakousko }\end{array}$ & 50 & $2017-2020$ \\
\hline 12 & Ústí nad Orlicí - Lichkov st. hr. Polsko & 20 & $2018-2020$ \\
\hline 13 & Kolín - Nymburk - Mělník - Děčín východ - Děčín-Prostřední Žleb & 100 & after 2020 \\
\hline 14 & Kolín - Havlíčkøuv Brod - Brno & 100 & after 2020 \\
\hline 15 & Praha - Lysá nad Labem & 30 & after 2020 \\
\hline 16 & Praha - Letiště V. Havla Ruzyně - Kladno & 20 & after 2020 \\
\hline 17 & Praha - Beroun & 30 & after 2020 \\
\hline 18 & Plzeň - Domažlice st. hr. Německo & 40 & after 2020 \\
\hline 19 & Pardubice - Hradec Králové & 20 & after 2020 \\
\hline 20 & Plzeň - České Budějovice & 50 & after 2020 \\
\hline 21 & Brno - Přerov & 60 & after 2020 \\
\hline 22 & Hranice na Moravě - Horní Lideč st. hr. Slovensko & 30 & after 2020 \\
\hline 23 & Uzel Praha & 20 & after 2020 \\
\hline 24 & Český Těšín - Ostrava-Svinov & 20 & after 2020 \\
\hline 25 & Velký Osek - Hradec Králové - Choceň & 40 & after 2020 \\
\hline 26 & Cheb - Karlovy Vary - Chomutov & 50 & after 2020 \\
\hline 27 & Ústí nad Labem - Chomutov, Ústí nad Labem - Bílina & 50 & after 2020 \\
\hline & TOTAL & 1550 & \\
\hline
\end{tabular}

TABLE 3. Expected track deployment of ETCS L2 3]

After 2020 will be deployed around $250 \mathrm{~km}$ tracks and 150 vehicles every year until 2026 .

Strategies transition from the current national system VZ SS to European interoperable system Class A - ETCS consists a combination of investment in track equipment and train equipment. In the first phase will be equipped only international traffic trains.

During migration will vehicles equipped with ETCS parallel with VZ LS that allow operation of both systems together.

ETCS should be fully migrated for first and second rail corridor and the track Přerov - Česká Třebová at the latest to 2030 .

After the migration period will be completely decommissioned national systems VZ LS and fully deployed ETCS system.

In some cases can be deployed new special sections equipped solely with ETCS, which will be designed to operate only vehicles equipped with ETCS even before end of migration period. i.e. a railway connection Václav Havel airport Prague and Prague center.

\section{Deployment of ERTMS in other EUROPEAN COUNTRIES}

Unification of Europe requires to all transport systems operates without restrictions and time losses, especially when crossing borders.

The Deployment started in most of European Union countries. Following countries started participation on deployment of the ERTMS standard: Austria, Belgium, Bulgaria, Croatia, Czech Republic, Denmark, Finland, France, Germany, Greece, Hungary, Italy, Luxembourg, Netherlands, Poland, Romania, Slovakia, Slovenia, Spain, Sweden and United Kingdom.

The Figure 7 displays amount of kilometers contracted tracks for each country.

The Figure 8 displays covering of the ERTMS divided by level of tracks.

The Figure 9 displays amount of deployed on-board equipment of vehicles for each country.

The Figure 10 displays levels of on-board equipment implemented in vehicles. 


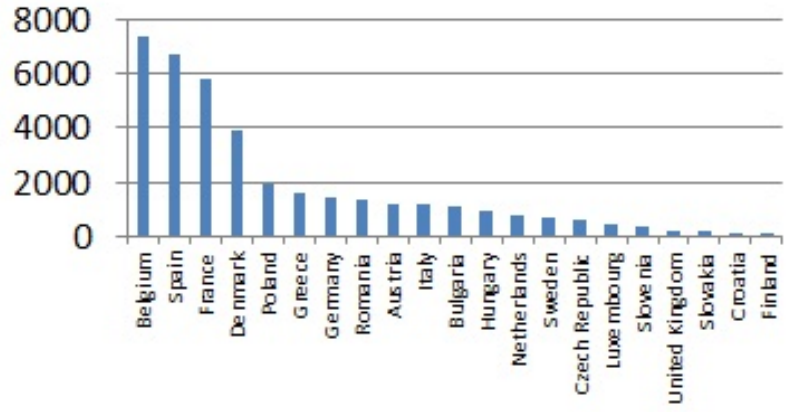

Figure 7. ERTMS contracted tracks $[\mathrm{km}]$ in EU

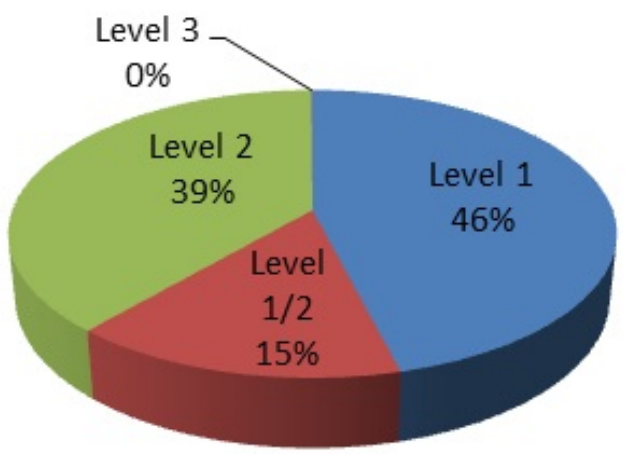

FiguRE 8. TRACKS in EU separated by level

\section{Conclusions}

By 2020 the GSM-R will cover major sections of the Rail Freight Corridors in the Czech Republic. The system will be further deployed progressively on all 3700 $\mathrm{km}$ of national routes in order to create comprehensive operational tracks.

ETCS deployment priority by 2020 is Rail Freight Corridor 7, partially corridors $8,9,5$ and the track Přerov - Česká Třebová.

By 2020, it is necessary to ensure the development of the ETCS about 1350 kilometers of tracks and 890 vehicles, ie. for additional six years, around 250 $\mathrm{km}$ of tracks and 150 vehicles every year, but this is conditional on the timely implementation of the modernization infrastructure.

This requires the necessary financial resources for the trackside and on-board ERTMS and creating mo-

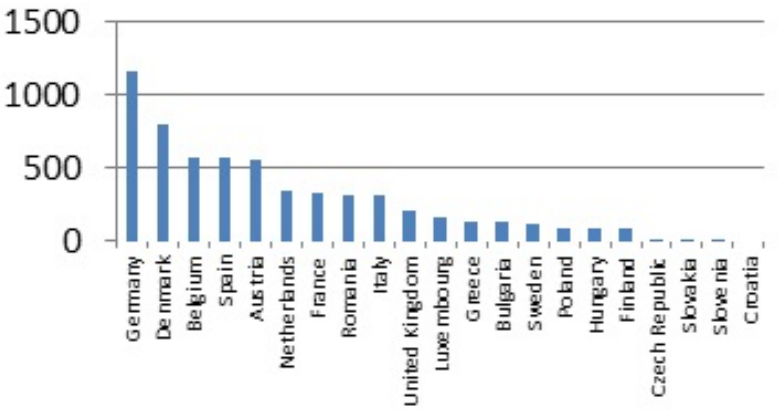

Figure 9. Global ERTMS vehicles contracted in Europe

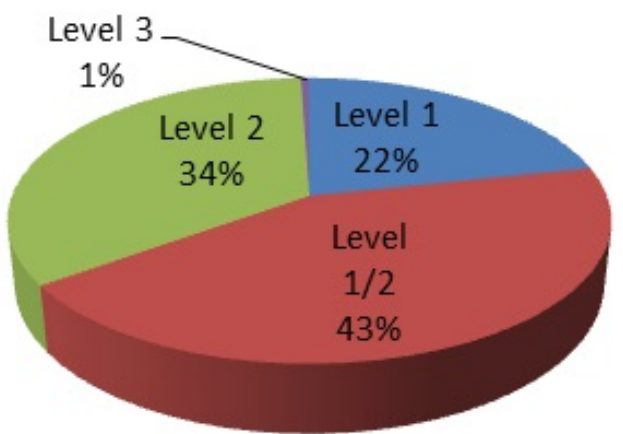

Figure 10. Vehicles in EU separated by level

tivational factors and efficient financial support equipping vehicles with on-board equipment of GSM-R and ETCS.

\section{REFERENCES}

[1] The European Rail Traffic Management System, Portál ERTMS [online]. [2016-02-12], http://www.ertms.net/?page_id=42

[2] Národní implementační plán ERTMS 2014-2020, Portál ACRI [online]. [2016-02-12], http://www.acri.cz/uploads/acri-akademie/15-06\% 20ETCS/2015_Cech,\%20Varadinov.pdf

[3] Národní implementační plán ERTMS, Portál ministerstva dopravy [online]. [2016-02-12], http://www.mdcr.cz/NR/rdonlyras/ 7FF4FAF1-1EBE-4116-BF90-808EC7306E04/0/ NIPERTMSNPweb.pdf 